\title{
Relationship of resistin levels with endometrial cancer risk
}

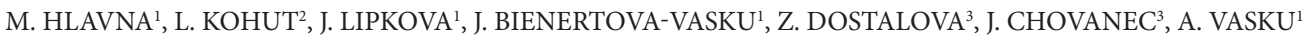

${ }^{1}$ Institute of Pathological Physiology, Faculty of Medicine, Masaryk University, Kamenice 5, Brno, Czech Republic, 625 00, e-mail: marian. hlavna@biomania.cz; ${ }^{2}$ Institute of Biostatistics and Analyses, Masaryk University, Brno, Czech Republic, ${ }^{3}$ University Hospital Brno, Department of Obstetrics and Gynecology, Brno, Czech Republic,

\section{Received September 22, 2010}

\begin{abstract}
Cancer of endometrium (CAE) is the most common gynecologic malignancy in industrialized nations. Increased resistin levels, an adipocytokine produced by adipose tissue and macrophages, have been considered as a risk factor in gastric, colon and breast cancer, recently. No studies associating resistin levels with endometrial cancer have been done so far. The purpose of this case-control study was to determine the relationship between serum circulating resistin levels and resistin gene $-420 \mathrm{C}>\mathrm{G}$ (rs3219175) variant in endometrial cancer patients. 37 Caucasian female patients and 39 healthy controls were enrolled in this study. Difference in resistin levels between age and BMI matched patients group (mean $24.2 \mathrm{ng} / \mathrm{ml}$ ) and control subjects (mean $10.1 \mathrm{ng} / \mathrm{ml}$ ) were statistically significant $(\mathrm{p}<0.01)$. We also determined single nucleotide polymorphism $-420 \mathrm{C}>\mathrm{G}$ (rs3219175) within resistin gene and no significant association between resistin levels and investigated polymorphism was found. Furthermore, no significant association between higher resistin levels and diabetes mellitus 2, body mass index, smoking or age have been observed within studied groups. To our knowledge, this is the first study examining the relationship between serum resistin levels and endometrial cancer and our results show, that patients with endometrial cancer have significantly increased circulating levels of resistin compared to control subjects.
\end{abstract}

Key words: Endometrial cancer, resistin, SNP $-420 C>G$

Cancer of endometrium (CAE), the neoplastic growth of endometrial epithelial cells, is the most common gynecologic malignancy in industrialized nations. Worldwide, it is diagnosed approximately 142000 new endometrial carcinomas and approximately 42000 women die of the disease every year. In the Czech Republic, the incidence has slightly increasing trend and in 2007 reached number 33/100 000 women [1]. In numbers, approximately 1796 new cases have been diagnosed and 567 women died in Czech Republic in 2007. CAE incidence rises dramatically following the menopause with climax in $6^{\text {th }}$ decennium. Therefore increasing incidence trend could be explained by prolonged life-span and increased exposure to risk factors. Well-known risk factors, which are involved in carcinogenesis of CAE are obesity, hypertension, diabetes mellitus 2 , nulliparity, polycystic ovarian disease, use of estrogen medications that lead to unopposed estrogenic stimulation of the endometrium [2] and newly also inflammatory processes are considered as another important feature proposed to influence cancer development. Although, this risk factors are known for many years, the molecular mechanisms of endometrial cancer development and contribution degree of known risk factors in this process, especially obesity and diabetes mellitus 2 , are still not fully understood. In last decade, the discovery that adipose tissue is not only energy-storage organ but active metabolic tissue, could answer many questions and shed a light on links between obesity, diabetes mellitus, cancer and other clinical features. The white adipose tissue acts as an active endocrine organ secreting multiple metabolically important proteins - 'adipocytokines', involved in physiological functions such as energy homeostasis, immunity and inflammation $[3,4]$. One of the relatively new identified adipokine is gene encoding for resistin (RETN). After its initial discovery in mice, it was suggested to be the link between obesity and type 2 diabetes. Steppan et al.. [5] demonstrated that resistin expression was increased in obese animals, and moreover, administration of recombinant resistin to normal animals produced insulin resistance $[5,6]$. When considering resistin involvement in pathophysiology of obesity and diabetes mellitus 2 in humans, resistin studies have produced contradictory findings. Although some studies reported increase of resistin in obesity and diabetes type 2, most did not show correlation between resistin circulating levels and body mass index or insulin resist- 
ance [7-10]. This contrast could be caused by fact, that human and mouse RETN genes share only 53\% homology, therefore their functions may differ between them [11] and other roles of RETN may exist in human. Although the exact function of resistin in human is still not known, increased resistin levels have been associated with coronary heart disease [12-15] and considered as a risk factor in gastric, colon and breast cancer [16-19], recently. The purpose of this case-control study was to determine the relationship between serum circulating resistin levels and resistin gene $-420 \mathrm{C}>\mathrm{G}$ (rs3219175) variant in endometrial cancer patients.

\section{Patients and methods}

Subjects. Thirty seven Caucasian female patients and 39 healthy controls were enrolled in this study. Recruited patients were diagnosed for endometrial cancer and treated at a University Hospital Brno at Department of Obstetrics and Gynecology. Complete anamnesis, anthropometric measurements and medical documentation including blood tests and histology of endometrial tumor have been obtained. Healthy women with no previous history of any kind of cancer, with similar age and body mass index (BMI) were recruited as controls. For correct statistical analysis of resitin we matched 25 patients and 25 control subjects by age and BMI. All participants gave their written informed consent before they entered the study. This study was approved by the Committee for Ethics of Medical Experiments on Human Subjects, Faculty of Medicine, Masaryk University, Brno and was performed in adherence to the Declaration of Helsinki Guidelines.

Genotype analysis and serum level measurements. Blood samples were obtained from all individuals in EDTA anticoagulant and DNA was isolated by the salting-out method. Purity and concentration was measured on nanodrop spectrophotometer. Genotyping of $-420 \mathrm{C}>\mathrm{G}$ SNP (rs1862513) within resistin gene sequence was performed by polymerase chain reaction (PCR) and consequent restriction fragment length polymorphism (RFLF). Primers (forward primer $5^{\prime}$ - TTT TGT CAT GTT TGC ATC AGC - 3‘; reverse primer 5 ' - GGG CTC AGC TAA CCA AAT - $3^{c}$ ) were designed within resistin gene and its promoter sequence, carried in SNPper database (http://snpper.chip.org) which corresponds to contig NG_023447.1 (www.ncbi.nlm.nih.gov). 330-bp fragment was amplified by standard Taqman polymerase under following amplification conditions: total volume of $25 \mu \mathrm{l}$ containing 150 ng genomic DNA, initial denaturation $94^{\circ} \mathrm{C}$ for 3 minutes, then 31 cycles of $94^{\circ} \mathrm{C}$ for 30 seconds, $55^{\circ} \mathrm{C}$ for 15 seconds, $70^{\circ} \mathrm{C}$ for 30 seconds, and $70^{\circ} \mathrm{C}$ for 10 minutes and consequently digested by endonuclease restriction enzyme BbsI (NEB, USA) under manufacturers recommendations. Results have been evaluated by single strand conformation polymorphism (SSCP) method.

Blood drawings for biochemical examinations were performed in the morning after 12 hour fasting. After serum separation were samples frozen at -20 degrees. Serum resistin level was measured by Enzyme-linked immunosorbent assay (ELISA), using human resistin ELISA kit (R\&D Systems, USA). Intra- and inter-assay precisions were less than 5.3 and $9.2 \%$, respectively. The minimum detectable dose of resistin was $0.055 \mathrm{ng} / \mathrm{mL}$.

Statistical analysis. Basic descriptive statistics were used for general characterization of measured data. Considering quite low amount of patients and controls, median (and 5th and 95th percentile) was used as main characteristic. For correct usage of statistical method was necessary to test the normality of each quantitative trait. This was performed by histogram (Phi-Square) and Kolmogorov-Smirnov test. All evaluated parameters were significantly different from normal distribution. Thus we decided to use only non-parametric methods. For testing of dichotomic parameters (e.g. diabetes, smoking) was used Mann-Whitney test. To examine relations between continuous and categorical parameters with more than two categories (genotype), Kruskall-Wallis ANOVA was performed. P-values below the conventionally agreed level of significance $(p<0.05)$ were considered statistically significant. For determine adiposity were set cohorts stratified by baseline BMI $=25$ which allowed match patients and controls for BMI and age (tested by M-W test). All results were carried out using software Statistica (version 9.0; StatSoft inc. (2009)).

\section{Results}

Standard robust summary statistics were used to describe distribution patterns in the primary data (mean, minimum, maximum). These are shown in Table1. The mean age of all participants was $49 \pm 13.5$ years whereas patients had in average 57 years and controls 42 years. After creation of matched groups, the mean age changed quite slightly to 52 years (with range $26-61$ ) and 48 years (with range $38-67$ ) in group of patients and controls respectively. Homogeneity of age between groups was approved by Mann-Whitney test $(p=0.07)$. For matched groups was also performed testing of BMI. Computed mean value of BMI was 31.5 and 30.9 for patients and controls respectively. Difference in BMI between groups was not observed $(\mathrm{p}=0.36)$. When we compared concentration of resistin between matched groups, the mean level was $24.2 \mathrm{ng} / \mathrm{ml}$ and $10.1 \mathrm{ng} / \mathrm{ml}$ in group of patients and controls respectively. The test proved statistically significant difference between groups $(\mathrm{p}<0.01)$. It was necessary to test relationship between serum resistin level and BMI and between resistin level and age for each group separately. As

Table 1. Basic characteristics of patients and control subjects

\begin{tabular}{lcccc}
\hline & Control subjects $(\mathrm{n}=25)$ & Patients $(\mathrm{n}=25)$ & Z-value & $\mathrm{p}$-value \\
\hline Resistin & $9.44(4.84 ; 14.94)$ & $23.50(7.8 ; 44.3)$ & 4.66 & $<0.01$ \\
Age & $46.7(39.8 ; 61.3)$ & $54.0(38.0 ; 61.0)$ & 1.83 & 0.07 \\
BMI & $24.7(20.6 ; 48.1)$ & $31.2(21.9 ; 44.5)$ & 0.91 & 0.36 \\
\hline
\end{tabular}


measure of this relationship was applied Spearman correlation metric. Results are in Table2.

We investigated whether the difference in serum resistin level between patients and control subjects is associated with resistin natural variant $-420 \mathrm{C}>\mathrm{G}$ polymorphism. All patients and control subjects were genotypized for mentioned polymorphism. These genotypes were divided into three groups (CC, CG, GG) and resistin dependency was tested by Kruskall-Wallis Anova (nonparametric one-way Anova). Dependency of serum resistin levels on genotype was not statistically significant (for control subjects $\mathrm{p}=0.39$; patients $\mathrm{p}=0.72$ ). Genotype distribution between patients and control group was tested by phi-square test and genotype distribution did not show any significant differences $(\chi=0.567 ; p=0.75)$. For determination of similarity between genotypes associated with resitin levels (within each group separately) was used Tukey's HSD test (Table 3). The most different are GC and CC genotypes, within patients group $(\mathrm{p}=0.75)$ and control group respectively $(p=0.36)$, both of them are not significant. We have also found non-significant relationship between resistin levels and diabetes mellitus type $2(\mathrm{p}=0.707)$ hypertension $(\mathrm{p}=0.948)$ or smoking $(\mathrm{p}=0.272)$.

\section{Discussion}

Resistin is a member of the adipokine family and in initial studies has been reported, that resistin can cause insulin resistance and decrease adipocyte differentiation in rodents $[5,6]$. However, similar studies attempting to associate serum resistin

Table 2. Spearman correlations within patients' group and control subjects

\begin{tabular}{lccclcccc}
\hline & \multicolumn{3}{c}{ Patiens } & \multicolumn{4}{c}{ Control subjects } \\
\hline & Resistin & Age & BMI & & Resistin & Age & BMI \\
Resistin & 1.00 & -0.27 & -0.08 & Resistin & 1.00 & -0.12 & 0.09 \\
Age & -0.27 & 1.00 & 0.16 & Age & -0.12 & 1.00 & 0.39 \\
BMI & -0.08 & 0.16 & 1.00 & BMI & 0.09 & 0.39 & 1.00 \\
\hline
\end{tabular}

Table 3. Similarity of resistin levels associated with resistin gene $-420 \mathrm{C}>\mathrm{G}$ genotype within patients and control subjects.

\begin{tabular}{lccc}
\hline & \multicolumn{3}{c}{ Patients } \\
\hline Genotype & $\mathrm{CC}$ & $\mathrm{GC}$ & $\mathrm{GG}$ \\
CC & $\mathrm{x}$ & 0.75 & 0.98 \\
GC & 0.75 & $\mathrm{x}$ & 0.82 \\
GG & 0.98 & 0.82 & $\mathrm{X}$ \\
\hline
\end{tabular}

\begin{tabular}{lccc}
\hline \multicolumn{3}{c}{ Control subjects } \\
\hline Genotype & CC & GC & CG \\
CC & $\mathrm{x}$ & 0.36 & 0.86 \\
GC & 0.36 & $\mathrm{x}$ & 0.94 \\
GG & 0.86 & 0.94 & $\mathrm{x}$ \\
\hline
\end{tabular}

levels or its natural SNP variants to insulin resistance, diabetes 2 or obesity in humans brought discontinuous results [7-12]. These discrepancy findings led to suggestion, that resistin could exhibit in humans other physiological functions than in rodents. Although, the biological activity of resistin is not very clear, in recent years have been published studies linking increased serum resistin levels with occurrence of gastric [16], colon [17] and breast cancer [18,19]. Furthermore, in the last cited study elevated levels of resistin were positively correlated with the size of breast cancer tumor.

Based on these recent findings and observations, we hypothesized that patients with endometrial cancer would show alternation in serum resistin levels comparing with control subjects. To our knowledge, this is the first study examining the relationship between serum resistin levels and endometrial cancer and our measurements show, that patients with endometrial cancer have significantly increased circulating levels of resistin compared to control subjects. Some studies showed that there might be a correlation between higher serum resistin levels and higher BMI and obesity [20,21], however contradictory studies have been published so far $[22,23]$. Majority of our enrolled patients had BMI higher than $>25$, thus we have been interested whether serum resistin levels in our cohort depend on BMI. The observation made separately among control subjects and patients in this study revealed that serum resistin levels were not positively correlated with BMI. Furthermore, the association between serum resistin concentration and occurrence of endometrial cancer remained after adjustment for BMI and age.

Osawa et al.. found correlation between $G / G$ natural variant of $-420 \mathrm{C}>\mathrm{G}$ polymorphism and higher level of circulating resistin in Japan diabetes mellitus type 2 patients. According to authors, this could be explained by specific recognition of $-420 \mathrm{G}$ by $\mathrm{Sp} 1 / 3$, which increases RETN promoter activity, leading to enhanced serum resistin levels [24]. Also other studies on indicating that $-420 \mathrm{C}>\mathrm{G}$ variant within resistin gene promoter could be connected with higher serum levels $[25,26]$. In contrary, we did not observed any association between serum resistin levels and -420G RETN variant. Moreover, the investigated polymorphism did not express any deviation in allele distribution from Hardy-Weinberg equilibrium within patients and controls group. Although our results do not correspond with previously mentioned studies, they are in compliance with recent work of Onum et al. on Japan cohort. Authors investigated other polymorphism within RETN gene named -358A, which is compound with $-420 \mathrm{G}$ and both of them are required to confer higher serum resistin levels. In Caucasians, the association between SNP-420 and plasma resistin is not strong, and A at -358 may not exist, suggesting that SNP-358 could explain this ethnic difference [27]. Unfortunately, we did not investigate -358A polymorphism, so we can not confirm Onum's hypothesis. In addition, measured resistin levels in our study did not show any correlation with smoking, diabetes mellitus type 2 or hypertension. 
In other words, based on our results resistin appears to have diabetes mellitus type 2 , hypertension, smoking, age, adiposity and resistin SNP $-420 \mathrm{C}>\mathrm{G}$ independent link to endometrial cancer. Although the underlying mechanisms of this association are not clear, there are some suggestions why are higher serum resistin levels associated with gastric, colon, breast cancer and newly based on our findings also with endometrial cancer.

It has been published that even resistin is produced by adipose tissue, macrophages are more important source of resistin in humans [28]. Bokarewa et al. found that resistin exert potent pro-inflammatory properties by up-regulating pro-inflammatory cytokines, probably via NF-kB pathway [29].

In addition, recent data indicate that stimulation of macrophages in vitro with endotoxin or pro-inflammatory cytokines leads to a marked increase in resistin production [30]. In other clinical studies, resistin have been associated with inflammatory markers apparently independent on BMI, but related to risk factors of atherosclerosis $[31,32]$. Together with facts that up-regulated pro-inflammatory cytokines and chemokines in tumors [33-35] and inflammation itself is recently recognized as risk factor contributing on cancer development and progression [36-39], resistin seems to be a novel secreted protein in relation to inflammation in humans and may present molecular link between inflammation and carcinogenesis.

Several limitations need to be considered when interpreting our findings. Firstly, this initial study was done on relatively small cohort therefore we agree that larger studies to validate our results need to be done. In this study we use only two single measurements of baseline levels of resistin, from one collected serum, which may subject to error regarding its ability to reflect the true status of circulating resistin. However, previous studies suggest that blood levels of resistin have a relatively low intrasubject variation over time [32] and this may reliably reflect the long-term resistin levels in adult women. Even likely, we can not elucidate whether or not higher serum resistin levels are indeed caused by production of resistin in endometrial cancer cells. All this facts need to be taken in account when considering our findings.

To conclude, the present study provides evidence that endometrial cancer patients had significantly higher serum levels of resistin compared to those without endometrial cancer. Converging lines of evidence from this study and earlier in vitro and case-control studies offer the background biological context for considering resistin as a novel link between inflammation and cancer. Further studies to fully understand the mechanisms underlying resistin's effect and contribution on cancer development/progression need to be done. It is on our best behalf to keep studying well-known and newly discovered risk factors as well, and their role in process of carcinogenesis

\section{References}

[1] DUSEK L, MUZIK J, KUBASEK M, KOPTIKOVA J, ZALOUDIK J, et al. Epidemiology of Malignant Tumours in the
Czech Republic [online]. Masaryk University, Czech Republic, 2005, [cit. 2010-9-21]. http://www.svod.cz. Version 7.0, 2007, ISSN $1802-8861$

[2] TRAYHURN P, WOOD IS. Adipokines: inflammation and the pleiotropic role of white adipose tissue. Br J Nutr 2004; 92: 347-55. doi:10.1079/BJN20041213

[3] KURMAN RJ, MCCONNELL TG. Precursors of endometrial and ovarian carcinoma. Virchows Arch; 456: 1-12. doi:10.1007/s00428-009-0824-9

[4] BASTARD JP, MAACHI M, LAGATHU C, KIM J, CARON $\mathrm{M}$, et al. Recent advances in the relationship between obesity, inflammation, and insulin resistance. Eur Cytokine Netw 2006; 17: 4-12.

[5] STEPPAN CM, BAILEY ST, BHAT S, BROWN J, BANERJEE $\mathrm{R}$, et al. The hormone resistin links obesity to diabetes. Nature 2001; 409: 307-12. doi:10.1038/35053000

[6] RAJALA MW, OBICI S, SCHERER PE, ROSSETTI L. Adiposederived resistin and gut-derived resistin-like molecule-beta selectively impair insulin action on glucose production. J Clin Invest 2003; 111: 225-30.

[7] BECKERS S, PEETERS AV, FREITAS F, MERTENS L, HENDRICKX J, et al. Analysis of genetic variations in the resistin gene shows no associations with obesity in women. Obesity (Silver Spring) 2008; 16: 905-7. doi:10.1038/ oby.2007.131

[8] BIK W, OSTROWSKI J, BARANOWSKA-BIK A, WOLINSKA-WITORT E, BIALKOWSKA M, et al. Adipokines and genetic factors in overweight or obese but metabolically healthy Polish women. Neuro Endocrinol Lett;31.

[9] GHARIBEH MY, AL TAWALLBEH GM, ABBOUD MM, RADAIDEH A, ALHADER AA, et al. Correlation of plasma resistin with obesity and insulin resistance in type 2 diabetic patients. Diabetes Metab.

[10] ZOU CC, LIANG L, HONG F. Relationship between insulin resistance and serum levels of adiponectin and resistin with childhood obesity. Indian Pediatr 2007; 44: 275-9.

[11] STEPPAN CM, BROWN EJ, WRIGHT CM, BHAT S, BANERJEE R, et al. A family of tissue-specific resistin-like molecules. Proc Natl Acad Sci U S A 2001; 98: 502-6. doi:10.1073/ pnas.98.2.502

[12] FRANKEL DS, VASAN RS, D'AGOSTINO RB, SR., BENJAMIN EJ, LEVY D, et al. Resistin, adiponectin, and risk of heart failure the Framingham offspring study. J Am Coll Cardiol 2009; 53: 754-62. doi:10.1016/j.jacc.2008.07.073

[13] BUTLER J, KALOGEROPOULOS A, GEORGIOPOULOU V, DE REKENEIRE N, RODONDI N, et al. Serum resistin concentrations and risk of new onset heart failure in older persons: the health, aging, and body composition (Health ABC) study. Arterioscler Thromb Vasc Biol 2009; 29: 1144-9. doi:10.1161/ATVBAHA.109.186783

[14] PISCHON T, BAMBERGER CM, KRATZSCH J, ZYRIAX BC, ALGENSTAEDT P, et al. Association of plasma resistin levels with coronary heart disease in women. Obes Res 2005; 13: 1764-71. doi:10.1038/oby.2005.215

[15] CHEN C, JIANG J, LU JM, CHAI H, WANG X, et al. Resistin decreases expression of endothelial nitric oxide synthase through oxidative stress in human coronary artery endothe- 
lial cells. Am J Physiol Heart Circ Physiol; 299: H193-201. doi:10.1152/ajpheart.00431.2009

[16] NAKAJIMA TE, YAMADA Y, HAMANO T, FURUTA K, GOTODA T, et al. Adipocytokine levels in gastric cancer patients: resistin and visfatin as biomarkers of gastric cancer. J Gastroenterol 2009; 44: 685-90. doi:10.1007/s00535-009-0063-5

[17] AL-HARITHY RN, AL-GHAFARI AB. Resistin in human colon cancer. Increased expression independently of resistin promoter C-180G genotype. Saudi Med J; 31: 495-500.

[18] HOU WK, XU YX, YU T, ZHANG L, ZHANG WW, et al. Adipocytokines and breast cancer risk. Chin Med J (Engl) 2007; 120: 1592-6.

[19] KANG JH, YU BY, YOUN DS. Relationship of serum adiponectin and resistin levels with breast cancer risk. J Korean Med Sci 2007; 22: 117-21. doi:10.3346/jkms.2007.22.1.117

[20] YILMAZ M, BUKAN N, DEMIRCI H, OZTURK C, KAN E, et al. Serum resistin and adiponectin levels in women with polycystic ovary syndrome. Gynecol Endocrinol 2009; 25: 246-52. doi:10.1080/09513590802653833

[21] AZUMA K, KATSUKAWA F, OGUCHI S, MURATA M, YAMAZAKI $\mathrm{H}$, et al. Correlation between serum resistin level and adiposity in obese individuals. Obes Res 2003; 11: 997-1001. doi:10.1038/oby.2003.137

[22] SINORITA H, ASDIE RH, PRAMONO RB, PURNAMA LB, ASDIE AH. Leptin, Adiponectin and Resistin Concentration in Obesity Class I and II at Sardjito Hospital Yogyakarta. Acta Med Indones; 42: 74-7.

[23] BAJNOK L, SERES I, VARGA Z, JEGES S, PETI A, et al. Relationship of serum resistin level to traits of metabolic syndrome and serum paraoxonase 1 activity in a population with a broad range of body mass index. Exp Clin Endocrinol Diabetes 2008; 116: 592-9. doi:10.1055/s-2008-1065350

[24] OSAWA H, YAMADA K, ONUMA H, MURAKAMI A, OCHI $\mathrm{M}$, et al. The $\mathrm{G} / \mathrm{G}$ genotype of a resistin single-nucleotide polymorphism at -420 increases type 2 diabetes mellitus susceptibility by inducing promoter activity through specific binding of Sp1/3. Am J Hum Genet 2004; 75: 678-86. doi: $10.1086 / 424761$

[25] TSUKAHARA T, NAKASHIMA E, WATARAI A, HAMADA Y, NARUSE K, et al. Polymorphism in resistin promoter region at -420 determines the serum resistin levels and may be a risk marker of stroke in Japanese type 2 diabetic patients. Diabetes Res Clin Pract 2009; 84: 179-86. doi:10.1016/ j.diabres.2008.10.021

[26] HUSSAIN S, ASGHAR M, JAVED Q. Resistin gene promoter region polymorphism and the risk of hypertrophic cardiomyopathy in patients. Transl Res; 155: 142-7. doi:10.1016/j.trsl.2009.10.002

[27] ONUM H, TABARA Y, KAWAMURA R, TANAKA T, OHASHI J, et al. A at single nucleotide polymorphism-358 is required for $\mathrm{G}$ at -420 to confer the highest plasma resis- tin in the general Japanese population. PLoS One;5:e9718. doi:10.1371/journal.pone.0009718

[28] PATEL L, BUCKELS AC, KINGHORN IJ, MURDOCK $\mathrm{PR}, \mathrm{HOLBROOK} J \mathrm{D}$, et al. Resistin is expressed in human macrophages and directly regulated by PPAR gamma activators. Biochem Biophys Res Commun 2003; 300: 472-6. doi:10.1016/S0006-291X(02)02841-3

[29] BOKAREWA M, NAGAEV I, DAHLBERG L, SMITH U, TARKOWSKI A. Resistin, an adipokine with potent proinflammatory properties. J Immunol 2005; 174: 5789-95.

[30] FANTUZZI G. Adipose tissue, adipokines, and inflammation. J Allergy Clin Immunol 2005; 115: 911-9; quiz 920. doi:10.1016/j.jaci.2005.02.023

[31] SHETTY GK, ECONOMIDES PA, HORTON ES, MANTZOROS CS, VEVES A. Circulating adiponectin and resistin levels in relation to metabolic factors, inflammatory markers, and vascular reactivity in diabetic patients and subjects at risk for diabetes. Diabetes Care 2004; 27: 2450-7. doi:10.2337/ diacare.27.10.2450

[32] REILLY MP, LEHRKE M, WOLFE ML, ROHATGI A, LAZAR $\mathrm{MA}$, et al. Resistin is an inflammatory marker of atherosclerosis in humans. Circulation 2005; 111: 932-9. doi:10.1161/01. CIR.0000155620.10387.43

[33] SINGH RK, LOKESHWAR BL. Depletion of intrinsic expression of Interleukin-8 in prostate cancer cells causes cell cycle arrest, spontaneous apoptosis and increases the efficacy of chemotherapeutic drugs. Mol Cancer 2009; 8: 57. doi:10.1186/1476-4598-8-57

[34] FUJIMOTO J, AOKI I, KHATUN S, TOYOKI H, TAMAYA T. Clinical implications of expression of interleukin- 8 related to myometrial invasion with angiogenesis in uterine endometrial cancers. Ann Oncol 2002; 13: 430-4. doi:10.1093/annonc/ $\underline{\operatorname{mdf} 078}$

[35] SEO KH, LEE HS, JUNG B, KO HM, CHOI JH, et al. Estrogen enhances angiogenesis through a pathway involving plateletactivating factor-mediated nuclear factor-kappaB activation. Cancer Res 2004; 64: 6482-8. doi:10.1158/0008-5472.CAN03-2774

[36] SUN CA, WU MH, CHU CH, CHOU YC, HSU GC, et al. Adipocytokine resistin and breast cancer risk. Breast Cancer Res Treat; 123: 869-76. doi:10.1007/s10549-010-0792-4

[37] HARRIS RE, CHLEBOWSKI RT, JACKSON RD, FRID DJ, ASCENSEO JL, et al. Breast cancer and nonsteroidal antiinflammatory drugs: prospective results from the Women's Health Initiative. Cancer Res 2003; 63: 6096-101.

[38] OUAKAA-KCHAOU A, ELLOUMI H, GARGOURI D, KHARRAT J, GHORBEL A. Helicobacter pylori and gastric cancer. Tunis Med; 88: 459-61.

[39] WALLACE AE, GIBSON DA, SAUNDERS PT, JABBOUR HN. Inflammatory events in endometrial adenocarcinoma. J Endocrinol; 206: 141-57. 